\title{
PERJuANGAN M.A. SENTOt DALAM PERANG MEMPERTAHANKAN KEMERDEKAAN DI INDRAMAYU (1945-1949)
}

\author{
THE STRUGGLE OF M.A.SENTOT IN THE WAR \\ OF DEFENDING INDEPENDENCE IN INDRAMAYU (1945-1949)
}

\author{
Wahyu Iryana, Nina Herlina Lubis, Kunto Sofianto \\ Konsentrasi Ilmu Sejarah FIB Universitas Padjadjaran, \\ Jl. Raya Bandung Sumedang Km. 21, Jatinangor, Jawa Barat \\ e-mail:wahyu_iryana@yahoo.com,ninaherlinalubis@gmail.com, kunto.sofianto@unpad.ac.id
}

\begin{abstract}
Abstrak
Perang mempertahankan negara Indonesia pasca proklamasi kemerdekaan terjadi di beberapa daerah, termasuk perjuangan pasukan setan Muhammad Asmat Sentot di daerah Indramayu, Jawa Barat. Perlu ditekankan bahwa proses diplomasi tidak bisa dilepaskan dengan aktivitas militer. Adapun permasalahan yang diangkat dalam penelitian adalah mengenai bagaimana biografi Sentot sebagai pemimpin perjuangan perang fisik di Indramayu (1945-1949). Bagaimana perjuangan pasukan setan merah yang dipimpin oleh Sentot dalam mempertahankan kemerdekaan di daerah Indramayu Provinsi Jawa Barat. Penelitian ini bertujuan untuk mengetahui biografi Sentot dan untuk memahami nilai-nilai heroik perjuangan Muhammad As'ad Sentot melawan agresi militer Belanda dalam mempertahankan wilayah Indramayu. Tulisan ini menggunakan metode penelitian sejarah (heuristik, kritik, interpretasi, historiografi). Sedangkan teori yang digunakan adalah teori kausalitas. Hasil penelitian menunjukkan Sentot merupakan tokoh sentral dalam peristiwa perang fisik untuk mempertahankan kemerdekaan di wilayah Indramayu, Jawa Barat. Ia mempunyai peranan penting untuk membangkitkan serta mengobarkan keberanian rakyat Indramayu melawan Belanda pada masa perang fisik (1945-1949).
\end{abstract}

Kata kunci: perjuangan, Sentot, Indramayu.

\begin{abstract}
The war defended the post-independence Indonesian State of Independence in several areas, including the struggle of the red-blooded forces of Muhammad Asmat Sentot in the Indramayu area of West Java. It should be emphasized that the diplomacy process can not be separated by military activity. The problem raised in the research is about how the biography of Sentot as the leader of the physical war struggle in Indramayu (1945-1949). How is the struggle of red demon troops led by Sentot in maintaining independence in Indramayu area of West Java Province? This study aims to determine the biography of Sentot and to understand the heroic values of Muhammad As'ad Sentot struggle against Dutch military aggression in defending the Indramayu region. This paper uses historical research methods (heuristics, criticism, interpretation, historiography). While the theory used is the theory of causality. The result of this research is that Sentot is a central figure in the event of physical war to defend the independence in Indramayu, West Java. He has an important role to raise and brave the people of Indramayu against the Dutch during the period of the physical war (1945-1949).
\end{abstract}

Keywords: struggle, Sentot, Indramayu. 


\section{A. PENDAHULUAN}

Pasca proklamasi kemerdekaan 17 Agustus 1945, Belanda dengan membonceng NICA datang kembali ke tanah air Indonesia. Pada dekade tahun 1945-1949 di berbagai daerah terjadi peristiwa perlawanan untuk mempertahankan kemerdekaan. Jawa Barat ${ }^{1}$ merupakan salah satu wilayah Indonesia yang memang ikut berperan dalam memperjuangkan kemerdekaan bangsa pada masa revolusi. Hal tersebut terjadi karena kedudukan Jawa Barat sendiri yang merupakan basis dari pusat pemerintahan maupun tokoh pergerakan dari zaman penjajahan Hindia Belanda maupun Jepang. Maka tidak heran apabila wilayah Jawa Barat menjadi pelopor yang melahirkan berbagai badan perjuangan dan pusat berbagai pergerakan yang memunculkan tokoh yang di kemudian hari menjadi motor penggerak berbagai perubahan. Dari hal tersebut maka tidak heran apabila Jawa Barat menjadi daerah yang paling depan memperjuangankan kemerdekaan bangsa Indonesia (Tim Penerangan Umum Badan PenelitianPenjusunan Sedjarah Djawa Barat,1972: 278). Bukan hanya di basis-basis ibu kota namun daerah-daerah di pesisir utara Jawa Barat pun melakukan perjuangan, sebut saja di daerah Indramayu dengan pasukan setan merah yang di pimpin Muhammad Asmat Sentot (Selanjutnya disebut M.A. Sentot).

\footnotetext{
${ }^{1}$ Provinsi Jawa Barat merupakan provinsi yang telah dibentuk pada masa pemerintahan Hindia Belanda yaitu sekitar tahun 1925 dengan nama Provincie West Java yang membawahi wilayah Banten, Batavia, Priangan dan Cirebon. Lihat Edi S.Ekajati, Kebudayaan Sunda Jilid I: Kebudayaan Desa, (Bandung: Jurusan Sejarah Fakultas Sastra Universitas Pajajaran,1992),hlm.13. Sedangkan Nina Herlina dkk dalam buku Sejarah Provinsi Jawa Barat Jilid 2 menerangkan Bahwa Jawa Barat mulai dipakai sebagai nama Provinsi pada tanggal 19 Agustus 1945 dengan Soetradjo Kartohadikoesumo sebagai Gubernur pertama (Lubis, 2013:239-141).
}

Revolusi $^{2}$ memang mempunyai makna historis yang sangat mendalam bagi bangsa Indonesia. Menurut Sartono Kartodirdjo, revolusi Indonesia adalah proses politik yang penuh dengan konflik antara golongan, pemberontakan secara kolektif terhadap tatanan pemerintahan yang ada, di samping sebagai alat perjuangan untuk mempertahankan kemerdekaan (Kartodirdjo, 1992:16).

Masa revolusi nasional Indonesia pun merupakan salah satu rentang sejarah bangsa Indonesia yang memiliki peran sentral dalam pembentukan negara Indonesia. Pada masa revolusi, dinamika perkembangan Indonesia sangat terlihat. Hal itu disebabkan pada masa revolusi perkembangan sejarah mengalami perubahan yang sangat cepat. Tercatat berbagai peristiwa penting yang menentukan jalannya Indonesia ke depan terjadi pada masa revolusi ini. Berbagai penyerangan dan peperangan mempertahankan kemerdekaan, perjuangan diplomasi, sampai permasalahan dinamika politik dan masyarakat terjadi pada masa itu (J.S Reid, 1964:1).

Berbagai perjanjian damai yang telah disepakati, tak berlaku bagi pihak Belanda, hasrat mereka masih saja menggebu untuk tetap menjadikan Indonesia sebagai negara jajahan. Kerajaan

\footnotetext{
${ }^{2}$ Pemaknaan revolusi dikembangkan Charles Tilly yang merupakan bagian yang dijelaskan dalam teori collective action yang berpaham strukturis yang muncul pada abad ke-20 M. Dalam menjelaskan berbagai peristiwa, teori tersebut mengungkap semua aspek yang terlibat di dalamnya baik aspek sosial, ekonomi, politik, budaya maupun agama. Revolusi sendiri merupakan peristiwa yang mampu merubah aspek tersebut. Revolusi merupakan istilah yang diartikan sebagai peristiwa besar yang menyangkut semua aspek kehidupan manusia. Lihat Jurnal sejarah vol. 6 No. 1 Agustus 2004 , Pemikiran, Rekontruksi, Persepsi, Tilly "Collective Action" Revolusi Kisah Tawanan Boven Digul. Diterbitkan oleh Yayasan Masyarakat Sejarawan Indonesia. hlm.17.
} 
Belanda mengerti dan menyadari sepenuhnya bahwa memiliki negara jajahan itu mampu mendatangkan untung yang besar untuk negaranya, terlebih lagi negara jajahannya yang subur dan mempunyai kekayaan alam melimpah seperti Indonesia. Hal tersebut terbukti, Belanda yang dulunya tidak terlalu diperhitungkan di Benua Eropa, menjadi negara yang pertumbuhan ekonominya meningkat signifikan bahkan mapan secara finansial.

Pada masa perang fisik, di Indramayu mencuat seorang tokoh pejuang bernama Sentot, prajurit terpilih yang menjadi satu di antara Komandan Kompi dari Batalyon V. Sebelumnya ia menjadi Komandan Badan Keamanan Rakyat yang berpangkat Letnan Satu ditempatkan di Majalengka, dan sudah berpengalaman sebagai Komandan Kompi TKR di Kecamatan Anjatan.

Belanda melakukan agresinya yang pertama pada tanggal 21 Juli 1947, sebuah tindakan agresi yang secara jelas melanggar Perjanjian Linggarjati. Adapun satu butir isi di dalam kesepakatan itu menerangkan kedua belah pihak tidak boleh saling menyerang. Belanda yang mempunyai tabiat licik justru menuding bahwa Sukarno yang lebih dahulu melanggar perjanjian Linggarjati tersebut, dan mereka memakai dalih agresi ini dilakukan untuk menciptakan "rust en orde". Berbekal persenjataan perang lengkap dan canggih, Belanda mampu menguasai kota-kota besar Indonesia dalam kurun waktu yang singkat. Instruksi Soekarno kepada Jendral Soedirman adalah perang gerilya semesta hindari perang terbuka dijalankan dengan masif. Perang yang menggunakan strategi dan taktik secara diam-diam, namun sewaktuwaktu dapat melakukan aksi perlawanan secara mengejutkan yang terorganisir dan terstruktur (Nasution, 1984: 15-16).

Perang Gerilya semesta raya dijadikan strategi perang pasukan Sentot di Indramayu, suatu rasa tanggung jawab atas kewajiban (sense of obligation) yang tidak dimiliki oleh sembarang orang. Perjuangan pasukan Sentot akan dibahas dalam penelitian ini.

\section{B. METODE PENELITIAN}

Penelitian Perjuangan Sentot di Indramayu 1945-1949 menggunakan metode penelitian sejarah yang terdiri dari tahapan heuristik (pengumpulan data), kritik (analisis data), interpretasi, dan historiografi (penulisan kembali rekonstruksi sejarah). Sedangkan untuk teori, penulis gunakan teori kausalitas yaitu teori yang berbicara tentang sebab akibat terjadinya peristiwa sejarah, baik sebab langsung maupun tidak langsung. Dalam teori kausalitas, sejarawan menganalisis dua hal pokok, yaitu tentang kasus (peristiwa) dan perubahan. Keduanya berbeda dalam akibat yang ditimbulkan, karena kasus lebih bersifat prosesual tanpa perubahan, sedangkan dalam perubahan terjadi perubahan kausalitas berupa perubahan struktural (struktural change) dan perubahan sistem (systemic chenge) (Gottschalk, 1995; Kuntowijoyo, 2008: 3637).

\section{HASIL DAN BAHASAN 1. Biografi Sentot}

Sentot lahir pada tanggal 17 Agustus 1925 dengan nama Muhammad Asmat sebagai anak kempat dari delapan bersaudara. Ayahnya bernama H. Abdul Kahar dan ibu bernama Hj. Fatimah. Orang tua asli dari Plumbon Indramayu, tepatnya di Blok Lapangan Bola, Plumbon Indramayu. Dalam hal fisik ia memiliki ciri khusus yakni berupa tahi lalat di betisnya (Wawan Idris, 2008: 75).

Sejatinya M.A. Sentot berasal dari keluarga priyayi. Sejak kecil ia lebih senang "merakyat" daripada meninggininggikan status priayinya tersebut. Ia tidak memilih-milih dalam berkawan, serta tidak enggan berbaur bersama masyarakat yang secara ekonomi di bawah status keluarganya. Prinsip hidupnya yang demikian telah meniadakan kesenjangan sosial antara dirinya dengan rakyat pada 
umumnya. Hal itu pula, yang menjadikan tersohornya Sentot sejak kecil hingga remaja tidak hanya disebabkan oleh status ekonomi keluarganya yang memang merupakan keluarga terpandang di lingkungan tempat tinggalnya, namun karena pola pergaulan yang tidak mempedulikan strata sosial atau pun yang semacamnya.

Setelah menginjak remaja, M.A. Sentot mulai memperlihatkan wataknya yang membenci penjajah. Keingintahuannya yang besar mengenai kondisi rakyat Indonesia yang sedang terjajah sangat mengganggu pikirannya. Namun, dalam situasi yang belum memungkinkan untuk berjuang, M.A. Sentot remaja hanya bisa berangan-angan. Merujuk pada hal itu, ketika jauh sebelum M.A. Sentot menggeluti bidang kemiliteran dengan menjadi tentara Republik Indonesia, Ia telah mengindikasikan sikap yang anti penjajahan serta begitu peduli pada nasib bangsa Indonesia, khususnya rakyat Indramayu yang tengah mengalami masamasa sulit akibat dicengkram feodalisme dan kolonialisme bangsa Belanda. Terlebih orang tuanya juga sangat kontra dengan penjajah.

Orang tua M.A. Sentot memiliki pemikiran yang berseberangan dengan penjajah Belanda. Itulah sebabnya segala bentuk kegiatan, simpati, dan perbuatan yang menyokong keberadaan tentara Belanda sebisa mungkin dicegah oleh mereka (Wawancara Thohir (83), veteran Indramayu pejuang zaman Jepang dan salah satu prajurit yang ikut perang fisik).

Tidak mengherankan bila ia menjadi seorang yang seakan "alergi" terhadap para penjajah beserta segala hal yang menyertainya. Ia memahami, penjajahan di atas bumi tercintanya telah mengakibatkan berbagai kesengsaraan terhadap rakyat. Jiwa nasionalisme dan patriotisme yang tumbuh dengan sendirinya secara alamiah berdasarkan nurani dan realita yang terjadi, disatupadukan pula dengan ditanamkannya sikap anti penjajahan dari orang tuanya telah semakin mengukuhkan niat M.A. Sentot untuk menjadi pembela rakyat yang tertindas, tekad untuk melenyapkan penjajahan dari bumi tercinta, serta semangat untuk memperjuangkan bangsa dan negara. Demi mewujudkan cita-cita mulianya tersebut, masuklah ia ke dalam dunia militer dengan menjadi Tentara Republik Indonesia.

Berdasarkan keterangan resmi dari keluarga, M.A. Sentot pernah menjalani tiga jenjang pendidikan formal yang bersifat umum. Pendidikan pertama yang dijalaninya adalah Hollands Inlandsche School (HIS), selama tujuh tahun, lulus tahun 1940. Dilihat dari angka sejarah, pada tahun kelulusan itulah tentara-tentara Jepang memasuki wilayah Indonesia. Setelah Jepang masuk, semua sekolah yang bernuansa Belanda dibubarkan oleh mereka. M.A. Sentot baru menyelesaikan pendidikan setingkat Sekolah Menengah Pertama (SMP) setelah proklamasi kemerdekaan di tahun 1945. Pendidikan setingkat SMP ini ditempuh dalam waktu tiga tahun hingga lulus di tahun 1948. Setelah itu, kesempatan untuk menyelesaikan pendidikan setingkat Sekolah Menengah Atas (SMA) dijalaninya dengan mengambil SMA bagian A dan meraih kelulusan tahun 1954. Selain sekolah umum yang bersifat formal, ia juga sempat mengikuti pendidikan umum nonformal, yaitu kursus bahasa Inggris. Itulah sebabnya, sebagai prajurit ia cukup mampu berbahasa Inggris yang memang diperlukan dalam dinas kemiliteran (Wawancara Thohir (83), veteran Indramayu pejuang zaman Jepang dan salah satu prajurit yang ikut perang fisik).

Bila ditinjau dari riwayat M.A. Sentot, sebenarnya bahasa Inggris bukanlah satu-satunya bahasa asing yang ia kuasai. Berdasarkan pendidikan yang telah dijalaninya dan pengalaman pergaulan selama hidup di zaman penjajahan Belanda dan masa pendudukan Jepang, dapat disimpulkan bahwa M.A. Sentot mampu menguasai beberapa 
bahasa, yaitu bahasa Indonesia, Belanda, Jepang, Inggris, Jawa, dan Sunda. Perlu diketahui pula selain kemampuannya dalam berbahasa itu, ia juga dapat menulis, baik dalam huruf Latin maupun Arab.

Pendidikan militer pertama yang diikuti M.A. Sentot adalah pendidikan dan latihan yang diselenggarakan oleh dua pihak (para pimpinan calon Republik Indonesia, yang diwakili oleh Soekarno, dan pihak pemerintah Pendudukan Jepang). Nama pendidikan militer itu adalah Pembela Tanah Air (PETA). Pusat pendidikan dan latihan kemiliteran Peta terletak di Bogor, Jawa Barat. Di kota hujan itulah sejak 15 April 1943, M.A. Sentot mengikuti latihan kyookutai (latihan shodanco). Setelah mengikuti pendidikan secara intensif, M.A. Sentot lulus pada tanggal 1 Desember 1943 dan memperoleh sebutan Shodantyo. Untuk pertama kalinya ia memperoleh kedudukan sebagai Dai $N i$ Daidang di Majalengka kemudian pindah ke Jatibarang. Setelah itu, sebagai Dai Ni Cudan di Patrol Kecamatan Anjatan, Kabupaten Indramayu (Wawan Idris, 2008:68-69).

Jabatan pertama yang diembannya adalah sebagai Komandan BKR di daerah Kandanghaur, Kabupaten Indramayu pada tanggal 27 Agustus 1945. Setelah itu, pada tanggal 15 November 1945, dengan pangkat Letnan Satu, M.A. Sentot diangkat menjadi Danki III/Bn.IV/XI/SGDII di Indramayu, Jawa Barat. Setahun kemudian, tepatnya pada tanggal 7 Mei 1946, dalam pangkat yang sama, ia diangkat menjadi Dan Ki/Bn.V/V/SGD II di Majalengka, Jawa Barat. Berdasarkan pertimbangan dan tugas setelah itu, M.A. Sentot bertugas di daerahnya sendiri, Kabupaten Indramayu. Saat itu pangkatnya masih Letnan Satu, namun ia diberi tanggung jawab untuk menjadi Komandan Gerilya daerah Kabupaten Indramayu di bawah naungan Brigade V/I/Siliwangi mulai tanggal 21 Juli 1947, yaitu pada saat terjadi agresi militer Belanda ke-1.

Pada tanggal 27 Februari 1948, pangkat M.A. Sentot naik menjadi kapten.
Dalam pangkat ini ia menjadi Komandan Ki I/I/XIII/I Siliwangi di Tasikmadu, Solo, Jawa Tengah. Sepulang dari long march, pada 1 September 1948, dengan pangkat Kapten, ia menjadi Komandan Gerilya daerah Kabupaten Indramayu, Jawa Barat. Pada tanggal 1 Desember 1949, pangkatnya kemudian naik lagi menjadi Mayor dan bertugas menjadi Danyon A/KMB/I/IV/SLW di Indramayu berdasarkan Surat Keputusan dari Panglima Divisi IV Siliwangi No. 154/49. Dalam pangkat ini ia memperoleh lagi tiga pengalaman kemiliteran, yaitu menjadi Komandan Detasemen Subsitensi KMKB Bandung, Jawa Barat, berdasarkan Surat Keputusan dari Panglima Divisi IV/SLW G.M No. 261/2404/IV/SLW/1951 tanggal 1 Februari 1951, menjadi Staf Terr III di Bandung berdasarkan Surat Keputusan Np. 640/PM/PDS/52 dari Panglima Divisi IV Siliwangi tanggal 15 Oktober 1952, dan menjadi siswa SSKAD I Bandung sejak tanggal 24 Maret 1957 berdasarkan Surat Keputusan dari Panglima TT III/SLW no. 424/3/857 (Wawan Idris, 2008: 70).

Setelah lulus dari pendidikan kemiliteran di SSKAD, terhitung mulai 1 Juli 1957 pangkat M.A. Sentot naik menjadi Letnan Kolonel berdasarkan radiogram Kasad Nomor: TR-1453/1959. Dalam pangkat ini ia berturut-turut menjabat sebagai: Danyon 604/VI di Kotabaru, Kalimantan Selatan berdasarkan Surat Keputusan No. 773/12/1958 dari KASAD tanggal 10 Desember 1958, Asisten DEJAH KOANDA Kalimantan di Banjarmasin berdasarkan SP. No. 142/3/1959 tanggal 10 Maret 1959, sebagai Asisten II KOANDA Kalimantan berdasarkan SP no. 294/9.1960 dari DEJAH Kalimantan tanggal 19 September 1960, mewakili Kepala Staf DEJAH KOANDA Kalimantan, berdasarkan SP. 501/11/1960 berdasarkan Surat Perintah dari Dejah Koanda tanggal 9 September 1960. Karirnya kemudian menjadi Pamen Suad III di Jakarta berdasarkan Surat Perintah No. 48/2/1961 dari Dejah Koanda Kalimantan tanggal 6 Desember 
1961(Wawancara Thohir (83), veteran Indramayu pejuang zaman Jepang dan salah satu prajurit yang ikut perang fisik).

Tanggal 23 Maret 1963 menjadi Pamen Pok Hat Tek Corps Karya Angkatan Darat berdasarkan Surat Perintah No. 179/3/1963 dari Suad. Tiga tahun kemudian, tepatnya pada 31 Mei 1966, ia menjadi Asisten III Operasi Karya Angkatan Darat berdasarkan Surat Perintah dari Dan Ko Op Karya AD No. prin75/5/1966. Pada 1 Juni 1966, berdasarkan surat Keputusan Kasad No. Kep. 5/5/1966, dipindahkan dari Operasi Karya AD ke Mako Mabad sebagai Pamen Mako Mabad. Dalam daftar riwayat hidupnya, diketahui bahwa pangkat terakhir yang disandang M.A. Sentot adalah Kolonel, terhitung mulai 1 Oktober 1969. Setelah itu, ia menjadi Pamen Mabesad hingga pensiun pada September 1980 dan kembali ke tengah masyarakat di daerah Bugel, Patrol, Kabupaten Indramayu(Wawan Idris, 2008:71).

Sebagai prajurit tangguh di jajaran militer, khususnya Angkatan Darat, M.A. Sentot telah memperoleh beberapa tanda jasa yang menggambarkan kualitas pengabdiannya kepada bangsa dan negara. Tanda-tanda jasa yang pernah diterima, di antaranya Bintang Gerilya, Medali Sewindu Angkatan Perang Republik Indonesia dari Menteri Pertahanan, Mr. Ali Sastroamidjojo, pada 10 Oktober 1954, Satya Lencana 16 tahun, Satya Lencana PK I, Satya Lencana PK II, Satya Lencana Gom III, Satya Lencana Gom IV, Satya Lencana Gom V Lencana Penegak. (Wawancara Alamsyah, (66 tahun), anak kandung M.A Sentot). ${ }^{3}$

Ada sisi lain yang menarik dari seorang M.A. Sentot. Ia tidak hanya dikenal sebagai prajurit yang tangguh, tetapi juga terkenal memiliki kepandaian lain, yaitu bermain sepak bola. Kemampuannya bermain sepak bola sudah menonjol sejak muda dan ia terbiasa

\footnotetext{
${ }^{3}$ Pernyataan Alamsyah ini diperkuat dengan bukti fisik piagam penghargaan koleksi keluarga dari Almarhum Sentot.
}

bermain sebagai gelandang. Ia pernah aktif di PS Mars, anggota Persatuan Sepak bola Indonesia (Persib) Bandung pada tahun 1950-an.

M.A. Sentot tercatat memiliki sembilan orang anak. Pernikahannya yang pertama dengan $\mathrm{Hj}$. Siti Aliyah pada tanggal 8 Mei 1946 telah memberinya lima orang anak. Sementara pernikahannya yang kedua dengan $\mathrm{Hj}$. Faidah pada tanggal 12 Februari 1971 memberinya empat orang anak.

M.A. Sentot setelah pensiun dari pengabdiannya di jalur militer, di jajaran perwira menengah Angkatan Darat, ia memilih tinggal di rumahnya di daerah Bugel, Patrol, Kabupaten Indramayu. Hidup normal, meletakkan nama besarnya, serta tanpa mengembel-embelkan status atau prestasi yang telah ia torehkan sebelumnya. Berbeda halnya dengan para perwira militer lainnya yang ketika memasuki masa pensiun, maka secara umum melanjutkan karirnya dengan menekuni kancah perpolitikan nasional. Rekan dekat seangkatan, seperti Jenderal (alm) Umar Wirahadikusumah, misalnya, memilih aktif di jalur politik hingga sempat menjadi wakil presiden di masa Orde Baru. Padahal jika saja ia ingin memanfaatkan keadaan, sebenarnya sangat mungkin ia dijadikan sebagai "pejabat". Namun, M.A. Sentot bukan orang yang suka memanfaatkan keadaan. Pastinya ia sangat memegang teguh prinsip hidupnya, yang secara tersirat dapat disikapi bahwasannya, jika ingin menjadi "orang", tempuhlah dengan usaha sendiri.

Hingga masa tuanya, M.A. Sentot menolak diperlakukan istimewa. Pejuang sekaligus pahlawan Indramayu ini memilih hidup bersama rakyat kebanyakan. Ia menyatu dengan masyarakat di sekitarnya, hingga akhirnya wafat di Rumah Sakit Pertamina Cirebon pada 6 Oktober 2001 pukul 07.30 WIB dalam usia 76 tahun.Ia dimakamkan di TMP Cikutra Bandung (Wawancara Alamsyah, (66 tahun), anak kandung M.A Sentot). Untuk mengabadikan namanya, pemerintah 
Kabupaten Indramayu mengabadikan nama Sentot menjadi nama Rumah Sakit di Kecamatan Patrol Kabupaten Indramayu, Dengan mengabadikan nama M.A. Sentot untuk nama Rumah Sakit itu, siapapun yang melintas di jalur Pantura Indramayu bisa membaca namanya dengan mudah. ${ }^{4}$

\section{Perjuangan Sentot Masa Perang Fisik}

Secara kronologis, dibentuknya Pasukan Setan yang dipimpin Sentot yang ada di Indramayu pada masa kemerdekaan (1945-1947), tak lepas dari dampak agresi Belanda yang pertama. Kala itu Belanda melancarkan agresinya dengan kondisi pasukan yang prima, bersenjata lengkap, dan canggih. Demi menghindari penyerangan secara frontal oleh pihak Belanda, maka kesatuan resmi Tentara Republik Indonesia (TRI) diputuskan untuk dibubarkan. Dalam kondisi yang demikian, seluruh prajurit dari tentara Republik diinstruksikan untuk berpencar dan melanjutkan perjuangan dengan membentuk kelompok-kelompok gerilya bersama rakyat diberbagai tempat, sembari melakukan konsolidasi antarsesama laskarlaskar perjuangan.

Prajurit Batalyon VI segera membubarkan diri dan kembali ke kampung halamannya masing-masing untuk melanjutkan perjuangan dengan melakukan perang gerilya.

Kondisi itu membuat Letnan Satu M.A. Sentot terpanggil untuk kembali ke Indramayu dengan berjalan kaki. Bersama

4 Dalam nota administrasi pemakamannya, M.A. Sentot terdaftar dalam tulisan tangan Kantor TMP Cikutra Bandung, sebagai pahlawan dengan nomor urut 136. Dalam dokumen bertuliskan tulisan tangan itu nama M.A. Sentot dilahirkan di Indramayu pada 17 Agustus 1925, berpendidikan umum terakhir SMA, pendidikan militer PETA, berpangkat Kolonel dengan NRP 11893, berkesatuan terakhir di DEN MABESAD, tanggal wafat 6 Oktober 2001 dan dimakamkan 7 Oktober 2001 di lokasi C-I. Menurut petugas yang memelihara TMP Cikutra, M.A. Sentot dimakamkan pada 09.30 WIB. tiga orang anak buahnya melakukan konsolidasi untuk menyusun kekuatan. Anggota Batalyon VI yang membubarkan diri kembali dikumpulkan meskipun hanya berhasil membentuk satu regu dengan modal dua pucuk senjata karaben dan sepucuk pistol buldog. Merkas sementara mereka adalah di Desa Plumbon, tempat kelahiran M.A. Sentot. Di Indramayu, Letnan Satu M.A. Sentot membentuk pasukan sendiri beranggotakan orangorang pilihannya. Inilah cikal bakal Pasukan Setan yang menjadi "hantu" menakutkan bagi para serdadu Belanda. Betapa tidak, meskipun tentara Belanda dibekali persenjataan yang lengkap namun bisa kocar-kacir oleh ulah Pasukan Setan yang hanya bermodal senjata rampasan. Sebuah pasukan kecil yang justru sering menimbulkan kerugian besar di pihak Belanda.

Setelah berhasil membentuk satu regu yang berasal dari anggota-anggota Batalyon VI yang kembali dikumpulkan, kemudian mereka bersama-sama bertekad melanjutkan perjuangan dengan cara bergerilya. Pada saat itu M.A Sentot telah memiliki 13 orang prajurit, dan setelah berunding secara bersama-sama, memutuskan Desa Malangsemirang, Jatibarang, ditetapkan sebagai markas awal pasukannya.

Pada 1 Agustus 1947, Pasukan Setan mulai melakukan aksinya, yaitu mengganggu patroli-patroli tentara Belanda di jalan-jalan besar yang menghubungkan Indramayu dengan Jakarta. Pasukan Setan saat itu mampu melakukan mobilitas yang tinggi sehingga tak mudah dilacak kedudukannya. Mereka berpindah tempat setelah melakukan gangguan, secepat "setan" menghilang dari pandangan tentara-tentara Belanda yang terkejut karena serangan mereka. Salah satu senjata kebanggaan Pasukan Setan berupa Bren-gun, yang mereka juluki "si Untung", merupakan hasil rampasan ketika bentrok dengan tentara Belanda di Desa Larangan (Wawan Idris, 2008: 28). 
Suatu ketika, demi menghindari mata-mata pihak Belanda, serta untuk mendapatkan lokasi markas baru yang lebih strategis dalam rangka mengganggu pasukan-pasukan Belanda yang berkedudukan di pusat Kota Indramayu. M.A. Sentot memutuskan untuk memindahkan tempat markas pasukannya yang semula berada di Desa Malangsemirang ke Kampung Waledan dan Kujang di daerah Lamarantarung. Singkat kisah, kemudian M.A. Sentot mengirimkan utusannya guna bernegosiasi dengan warga kampung setempat, agar bersedia menjadikan Kampung Waledan dan Kujang itu sebagai markas.

Setelah berdiskusi dengan pasukan perintis dari kesatuan pimpinan M.A. Sentot, para ketua kampung menyetujui daerah mereka dijadikan markas pasukan gerilyawan. Sejak saat itulah, seluruh isi kampung menjadi tempat beristirahat, makan, minum, pijat, menyusun strategi dan basis penyerangan untuk mengganggu kesatuan-kesatuan tentara Belanda yang ada di Kota Indramayu dan sekitarnya.

Di kedua kampung tersebut, M.A. Sentot mengadakan penertiban dalam tubuh pasukannya, hal itu dilakukan karena personel yang berkumpul di Kampung Waledan dan Kujang sangat beragam. Komposisi pasukan disusun sebagai berikut:

$\begin{array}{lll}\text { Kepala Pasukan } & : & \text { M.A. Sentot } \\ \text { Pimpinan Staf } & : & \text { S. Soedimantoro } \\ \text { Koor Pertahanan } & : & \text { Tirtaatmaja } \\ \text { Koor Politik } & : & \text { R. Akhmad } \\ \text { Koor Pertahanan } & : & \text { Lili Sopandi } \\ \text { Rakyat } & & \\ \text { Kepala Regu I } & : \text { Husen } \\ \text { Kepala Regu II } & : \text { Sujogo } \\ \text { Kepala Regu III } & : \text { Hasan } \\ \text { Kepala Regu } & : \text { Ali Runajaya } \\ \text { ALRI } & : \text { Sutara } \\ \text { Kepala Regu } & \end{array}$

Berdasarkan perhitungan M.A. Sentot secara militer, untuk melindungi markas utama di Kampung Waledan dan
Kujang dari pihak Belanda, maka desadesa yang berada di sekitarnya dijadikan garis depan penyerangan (front). Adapun dari front yang dimaksud ialah terdiri dari Desa Arahan, Gandok, Cabang, dan Pecuk. Dengan penerapan yang demikian, Waledan dan Kujang dioptimalkan untuk tetap aman sebagai pos komando.

Pasukan M.A. Sentot disebut Pasukan Setan karena seluruh anggota pasukannya bisa menghilang. Konon, anggota Pasukan Setan ini memiliki kekuatan dan kesaktian yang luar biasa sehingga selalu lolos dari kepungan pasukan Belanda. Sekali waktu datang menyerang dan setelah itu langsung menghilang. Mereka menghilang tapi tidak kembali ke markas sehingga sulit dilacak oleh Belanda. Pasukan ini sungguh menjadi fenomena. Anggota mereka yang hanya berjumlah belasan orang sanggup mengobrak-abrik kantung-kantung kekuasaan Belanda. Simbol atau lambang pasukan ini sangat menyeramkan, yaitu berupa gambar tengkorak manusia yang diberi tanda silang di bawahnya dalam bendera berwarna dasar merah. Di bawah gambar tengkorak terdapat tulisan P.S. yang merupakan singkatan dari Pasukan Setan.

Setiap siang hari seluruh Pasukan Setan pimpinan M.A. Sentot beristirahat, kebanyakan tidur. Tempat tidur mereka di mana saja. M.A. Sentot sendiri sebagai Komandan tak memiliki tempat tidur khusus. Setelah malam tiba, barulah mereka meninggalkan kampung dan pergi ke kota untuk mengganggu kedudukan pasukan-pasukan Belanda. Kemunculan para gerilyawan sekitar jam tiga atau empat pagi sangat mengganggu kondisi Belanda. Mereka muncul secara tiba-tiba dan melakukan serangan. Setelah itu, mereka menghilang kembali ke hutan. Seperti setan, mereka bisa muncul kapan saja dan di mana saja, menyerang lalu menghilang.

Konsolidasi pasukan dari berbagai kesatuan dan kelaskaran yang berkumpul di Kampung Waledan dan Kujang 
sebenarnya merupakan pasukan gabungan. Disebut gabungan karena semua pasukan aliran apapun berkumpul di kampung itu. Tak hanya pasukan yang baik-baik, tetapi juga para pencoleng direkrut untuk membantu gerilyawan. Lama kelamaan mereka yang semula berperilaku menyimpang pun, yang tak tahu menahu kondisi negara, setelah mendengar dan menyaksikan sendiri tembakan-tembakan senjata milik pasukan Belanda menghancurkan wilayah dan kekayaan bangsanya, akhirnya berubah. Jiwa ksatria muncul untuk melawan penjajah dan menyalurkan keberaniannya untuk menyerang Belanda. Dengan bergabungnya mereka, sepak terjang Pasukan Setan semakin menjadi-jadi. Pada siang hari kondisinya sepi, namun malam hari "setan-setan" pasukan gerilya muncul menyerang aset-aset Belanda yang ada di kota-kota. Pagi harinya, pasukan kembali ke markas di Kampung Waledan dan Kujang.

Kampung Waledan dan Kujang sebenarnya bukan menjadi markas gerilya satu-satunya karena secara organisasi dan operasional, Pasukan Setan bertugas menyerang, menghadang, lantas menghilang. Jadi, mereka bergerak tanpa memiliki pos komando yang tetap. Justru dengan sifatnya yang seperti itulah Pasukan Setan menjadi pasukan yang sangat ditakuti musuh dan disegani kawankawan seperjuangan. Pasukan gerilya itu harum namanya dan menjadi idola serta kebanggaan masyarakat Indramayu.

Adapun salah satu aksi heroik yang dilakukan Pasukan Setan pimpinan M.A. Sentot itu ialah menghadang konvoi Belanda di Jembatan Bangkir. Dalam pertempuran itu, pihak Pasukan Setan mampu menewaskan puluhan tentara Belanda dan merampas semua senjatasenjata milik mereka. Peristiwa ini sangat terkenal dan membuat para petinggi Belanda yang bercokol di pusat Kota Indramayu menjadi geram dan memaksa harus kembali menyusun strateginya. Aksi dari Pasukan Setan itu telah membuka mata Belanda lebar-lebar, Belanda dipaksa harus mengakui bahwa kelompok gerilyawan di Indramayu tidaklah pantas diremehkan.

Keberhasilan penyerangan konvoi Belanda di Jembatan Bangkir pada November 1947 itu merupakan hasil penyerangan yang terencana. Sebelumnya, pasukan M.A. Sentot terlebih dahulu telah mendapat bantuan senjata dari polisi Belanda yang berada di bawah pimpinan Suhad, yang menggabungkan diri dengan pasukan Republik Indonesia, di Desa Anjatan. Dengan diperolehnya bantuan senjata ini, diadakan lagi penghadangan di Desa Kopiah dengan tujuan untuk menyelamatkan tawanan-tawanan yang akan dibawa Belanda ke Haurgeulis. Tawanan-tawanan tersebut akhirnya dapat diselamatkan. Sementara itu, tentara Belanda kocar-kacir meninggalkan banyak korban.

Sudah barang tentu pihak Belanda menjadi sangat marah atas segala sepak terjang dari pasukan gerilya pimpinan M.A. Sentot. Gangguan-gangguan dan penghadangan di berbagai tempat yang digencarkan oleh pasukan yang menamai diri sebagai Pasukan Setan itu membuat Belanda memutuskan untuk melakukan serangan besar-besaran dari semua arah, yakni darat dan laut. Dengan didukung serta peralatan canggih, semacam senjata loongser dan mengerahkan kendaraan tempur Bren carrier. Ancaman serangan Belanda tercium berkat informasi dari masyarakat sekitar. Suatu hari, pada 5 Desember 1947, datang informasi melalui Kadri (Kuwu Desa Terusan). Ia datang ke Pos Komando membawa surat dari Dr. Sudiro untuk M.A. Sentot. Isi surat itu memperingatkan agar kewaspadaan pasukan ditingkatkan karena ada kemungkinan tentara Belanda akan melakukan serangan besar-besaran ke basis pertahanan di Waledan dan Kujang. Informasi tersebut diperhatikan serius oleh M.A. Sentot. Ia paham, mata-mata Belanda berarti telah mencium keberadaan markas Pasukan Setan yang sebenarnya. Yaitu 6 
Desember 1947, datang lagi surat dari Dr. Sudiro ke Pos Komando. Pada kesempatan itu yang datang kembali menjadi kurir adalah Kadri. Isi surat itu menyarankan agar M.A. Sentot mengungsikan dahulu semua pasukan gerilya ke tempat yang aman karena tentara Belanda akan mengadakan serangan besar-besaran pada 7 Desember 1947. Serangan itu akan dilakukan dari tiga jurusan: darat, laut, dan udara. Dalam penyerangan itu, selain tentara Belanda, juga dikerahkan rakyat yang telah dihasut oleh Belanda dari Kota Indramayu dan Sindang. Isi surat itupun diperhatikan secara serius oleh M.A. Sentot.

Berdasarkan laporan-laporan yang disampaikan kepadanya itu, M.A. Sentot segera menginstruksikan agar semua pasukan yang berada di pos pengawas segera kembali kepada induk pasukannya masing-masing. Sementara itu, kepada pasukan yang ada di garis depan diinstruksikan agar tidak menyerang rakyat yang dijadikan perisai oleh tentara Belanda. Kemudian dianjurkan mengundurkan diri dan pula dilarang membalas sekalipun pihak lawan melepaskan tembakan.

Sesuai dengan peringatan yang telah diterima Pasukan Setan, serangan besarbesaran memang terjadi pada 7 Desember 1947. Sekitar pukul 06.00 pagi di Lamarantarung sudah terdengar suara tembakan-tembakan yang menandakan Pasukan Belanda sudah melakukan serangan. Dari arah Desa Pecuk, tentara Belanda dan rakyat sudah mulai bergerak mendekati Pos Komando. Semua pasukan gerilya di pos komando segera mengundurkan diri dan tidak melakukan perlawanan karena tentara Belanda ternyata menggunakan rakyat sebagai perisai.

Pada hari yang nahas itu, tiga unit pesawat terbang tempur milik Belanda meraung-raung, berputar mengelilingi angkasa Desa Waledan dan kujang. Pasukan Belanda secara frontal menembaki dari udara, menghujani dengan peluru ke arah rumah-rumah penduduk yang dicurigai sebagai tempat persembunyian para gerilyawan. Tentu saja rakyat menjadi panik, berhamburan ke luar mencari perlindungan, suasana kian mencekam dan kondisi ketika itu sangat kacau. Bahkan lama kelamaan tentara Belanda menjadi semakin beringas. Semua rumah mereka tembaki dari udara tanpa terkecuali. Penyerangan itu dilakukan setiap setengah jam sekali. Rakyat dan pasukan gerilyawan mencari tempat yang aman dan bersembunyi sebisa mungkin. Namun patut disyukuri ialah dalam peristiwa penyerangan besar-besaran oleh Belanda beserta warga yang telah dihasut ketika itu, para gerilyawan dan sebagian besar penduduk masih mampu meloloskan diri, walaupun ada beberapa yang tertembak meninggal ditempat. Adanya peringatan dini yang disampaikan Dr. Sudiro kepada M.A. Sentot sebelum penyerangan terjadi, sangat berguna untuk menghindari jatuhnya banyak korban dari para gerilyawan maupun penduduk desa. Selain dari hal itu pula, kemampuan penduduk menyelamatkan diri itu diperoleh berkat latihan yang instensif. Sebelum Pasukan Setan pimpinan M.A. Sentot menetap dan menjadikan kampung tersebut sebagai markasnya, para penduduk setempat telah dilatih perang oleh penduduk mereka sendiri yang ketika zaman pendudukan Jepang menjadi tentara yang dilatih oleh para tentara Jepang.

Seakan telah menang perang, tentara-tentara Belanda itu akhirnya memasuki dan menjarah setiap rumah. Semua perabot rumah tangga yang berharga, termasuk hewan peliharaan dan ternak, mereka bawa pulang. Serangan besar-besaran dari tiga arah (darat, laut, dan udara) itu baru berakhir sekitar pukul 17.00 waktu Indramayu saat itu. Tentaratentara infanteri Belanda pun kembali ke kesatuannya masing-masing di Kota Indramayu.

Setelah penyerangan berakhir, para gerilyawan dan penduduk yang mengungsi kembali ke rumahnya masing-masing. 
Serangan besar-besaran itu meninggalkan dendam yang mendalam terhadap pihak Belanda ataupun rakyat pribumi yang berkhianat. Kerugian yang diderita penduduk sungguh sangat tak ternilai, selain kerugian materiil, secara psikis pun para penduduk mengalami traumatis yang berat. Seusai berlalunya peristiwa tragis itu, pada malam harinya M.A. Sentot memerintahkan seluruh anggota gerilyawan untuk meninggalkan markas di Kampung Waledan dan Kujang. Serangan balik terhadap Belanda pun tidaklah dalam waktu yang tepat, bilamana hal itu dilakukan di tengah kondisi yang tak kondusif. Kendati dendam yang sangat membara di hati para gerilyawan, namun perang tidak bisa dilakukan secara emosional saja. Perang memerlukan taktik dan sekian perhitungan yang jitu. Pasukan M.A. sentot kemudian bergerak mencari daerah-daerah yang masih belum terlacak dan dianggap aman dari ancaman Belanda. Akhirnya M.A. Sentot memutuskan menempati Desa Sukamulya sebagai markas sementara pasukannya, sembari mereka beristirahat, mereka pun mengatur rencana-rencana selanjutnya. Pada posisi di Desa Sukamulya ini, pasukan M.A. Sentot tetap melakukan gangguan dan penghadangan terhadap patroli tentaratentara Belanda.

Perjanjian Renville ditandatangani oleh wakil pimpinan Republik Indonesia dan representatif dari pihak Belanda. Berdasarkan isi perjanjian tersebut, seluruh gerilyawan harus meninggalkan kantongkantong gerilya. Sebagai pasukan yang setia pada perintah pimpinan, para prajurit yang ada di kantung-kantung gerilya di Indramayu berjalan kaki pindah ke Majalengka. Mereka harus melalui Desa Ujungjaya, kemudian berkumpul di Desa Ciwaru. Di tempat itulah, setelah berjalan kaki selama tiga hari dan tiga malam, pasukan gerilya dari seluruh Karesidenan Cirebon berkumpul.

Setelah beristirahat selama beberapa hari, kemudian datang perintah yang mengintruksikan agar semua pasukan berkumpul di Kuningan. Tempat tersebut merupakan lokasi terakhir yang akan memberangkatkan seluruh pasukan menggunakan kereta api menuju Gombong, Jawa Tengah. Dari kota ini, pasukan melanjutkan perjalanan menuju Klaten, dan berakhir di Tasikmadu.

Seiring dengan hijrahnya M.A. Sentot beserta pasukan gerilyawan ke Yogyakarta pada bulan-bulan awal tahun 1948, disitulah letak jeda perjuangan Pasukan Setan pimpinan M.A. Sentot dalam mengganggu dan berupaya mengusir tentara-tentara Belanda yang bercokol di tanah Indramayu. Adapun kelanjutan dari perjuangan M.A. Sentot beserta pasukannya di daerah Indramayu, kembali dilancarkan pada bulan Agustus 1948, ketika para prajurit yang berada di bawah Komando Daerah Gerilya VI yang berhijrah pulang ke Jawa Barat.

\section{Pertempuran Melawan Belanda}

Perjuangan pasukan M.A Sentot melawan penjajah pada rentang waktu 1945-1947 puncaknya terjadi di saat agresi militer Belanda yang pertama. Pasukan Belanda dalam aksi agresinya menerapkan strategi tempur modern dengan mengandalkan jumlah tentaranya yang sangat memadai dan didukung persenjataan militer lengkap. Sementara itu, para pejuang kemerdekaan Indramayu menggunakan strategi perang gerilya. Seluruh pasukan gerilyawan melancarkan perjuangan dengan membentuk kelompokkelompok gerilya bersama rakyat di berbagai kampung, sembari melakukan konsolidasi antarsesama laskar-laskar perjuangan.

Mundurnya banyak kesatuan tentara dan kelaskaran lainnya ke kampungkampung bukan berarti pemerintah Republik Indonesia yang baru merdeka bertekuk lutut kepada pemerintah Kerajaan Belanda, melainkan hanya sebuah taktik perang. Di kemudian hari, strategi ini dikenal sebagai perang gerilya. Dalam keadaan tercerai berai oleh serangan membabi buta pasukan Belanda, para 
tentara, mantan tentara, dan anggota kelaskaran lainnya melakukan konsolidasi secara diam-diam. Setelah itu mereka melanjutkan perlawanan.

Adapun dengan penerapan strategi gerilya tersebut justru menjadi taktik yang ampuh. Aksi para gerilyawan teroganisir dan memiliki mobilitas tinggi, terlebih dengan manunggalnya para pejuang gerilya dengan rakyat. Hal itu penting, sebab pasukan gerilyawan menggunakan rakyat sebagai basis gerakan mereka. Jika rakyat tidak berpihak kepada para gerilyawan, mereka akan mudah ditangkap oleh pasukan Belanda.

Perjuangan masa itu memang sudah bukan lagi perjuangan Tentara Nasional Indonesia (TNI), melainkan perjuangan rakyat secara keseluruhan. Itulah sebabnya, segala sebutan atau istilah yang bernuansa militer seperti pangkat dan jabatan untuk sementara ditanggalkan. Setelah hal itu dilakukan, komposisi pasukan menjadi solid dan mampu melakukan gangguan kepada pihak Belanda secara signifikan.

Pada masa dan kondisi itu M.A. Sentot sebagai mantan shodantyo di tahun 1943 hasil didikan keras para prajurit Jepang, di tahun 1945 telah berpangkat Letnan Satu, berinisiatif untuk menggencarkan perjuangan melawan Belanda serta mempertahankan kemerdekaan di Indramayu. Dengan membentuk regu atau kelompok gerilyawan yang pada awalnya hanya dari anggota Batalyon VI, yang sebelumnya dibubarkan guna menghindari pembersihan tentara Republik oleh pihak Belanda. Markas awal mereka di Desa Plumbon tempat kelahiran M.A. Sentot. Hingga dalam perkembangannya regu pimpinan M.A. Sentot tersebut bertambah jumlah anggotanya, karena tidak sedikit anggota dari berbagai laskar pejuang serta rakyat yang bergabung.

Regu ini melakukan gangguangangguan dan penghadangan tentara Belanda. Sasaran utama gangguan dan penghadangan adalah Kota Indramayu dan sekitarnya. Sekali waktu, M.A. Sentot dan pasukannya menyerang Asrama Polisi Belanda yang berkedudukan di Pande Kecamatan Indramayu. Serangan malam itu dilakukan secara besar-besaran sehingga membuat asrama itu terbakar. Tidak kurang dari 19 rumah menjadi abu.

Menyikapi gangguan dan aksi dari para gerilyawan Indramayu membuat pihak Kerajaan Belanda yang berkedudukan di Indramayu tentu saja marah. Pada siang harinya mereka lantas melakukan patroli ke Desa Plumbon karena menurut dugaan mereka, serangan terhadap Asrama Polisi Belanda datang dari arah Pulmbon. Namun, M.A. Sentot dan pasukannya mengetahui adanya patroli dari tentara Belanda tersebut, kemudian ketika patroli itu melintas terjadilah kontak senjata sekitar lima belas menit. Setelah kontak senjata ini, M.A. Sentot dan kawankawan menghilang. Mereka menuju Desa Panyindangan Wetan dan melakukan konsolidasi kembali.

Setelah itu, mereka kembali melakukan penghadangan di Desa Lohbener. Sebuah mobil sedan milik Belanda hancur dibuatnya. Ketiga orang penumpangnya yang luka-luka segera melarikan diri ke kota. Di Desa Larangan, mereka pun kembali melakukan penyerangan sehingga menghancurkan sebuah mobil tangki air milik Belanda. Kasus ini segera tercium oleh induk pasukan Belanda di Indramayu. Mereka segera melakukan pembersihan, namun informasi tersebut bocor ke tangan gerilyawan sehingga pasukan Belanda tiba di tempat kejadian, M.A. Sentot dan kawan-kawannya sudah pindah ke Kampung Pecantilan, Cidadap, Desa Cikedung.

Dalam rentang waktu 1947 ini, selain melakukan pertempuran di Lohbener dan Larangan, pasukan gerilyawan pimpinan M.A. Sentot juga telah melakukan serangan di Desa Jambak dan penyerangan asrama tentara Belanda (KNIL) di Desa Penganjang yang merupakan bekas rumah Asisten Residen 
Indramayu di zaman penjajahan Belanda sebelumnya.

Setelah penyerangan-penyerangan itu, pasukan memasuki Desa Bugel pada malam hari menggunakan lima buah perahu. Dari Bugel mereka menuju Desa Bongas, di desa inilah mereka bertemu dengan pasukan Hassan (Laskar Jakarta). Satu setengah regu dari Laskar Jakarta menggabungkan diri ke pasukan M.A. Sentot. Dua hari setelah itu, mereka melakukan penghadangan terhadap pasukan Belanda yang menggunakan satu mobil pick-up penuh di Desa Bugel. Kontak senjata terjadi lagi sehingga menewaskan dua tentara Belanda. Belanda membalas serangan itu dengan membakar Desa Bugel. Namun ketika balasan dilakukan, pasukan M.A. sentot telah menghilang, kembali ke Desa Bongas. Pembakaran Desa Bugel, membuat rakyat marah sehingga mereka menghancurkan jembatan satu-satunya yang ada di desa itu. Harapan rakyat begitu bergantungnya terhadap M.A. Sentot dan laskar pejuang lainnya, karena penjajahan di atas tanah tercintanya sudah terlalu muak untuk dirasa. Rakyat menginginkan kehidupan yang tenteram, tiada ancaman yang mengincar atau gangguan keamanan yang membuat kepanikan. Pasukan Belanda yang kerap melakukan keganasan telah membuat banyak orang menderita, rakyat memerlukan bantuan dari militer Republik Indonesia, pada saat itu kelompok Gerilyawan M.A. Sentot muncul sebagai pembela rakyat yang tertindas. M.A. Sentot yang pantang kendur semangatnya terus memotivasi pasukannya untuk tiada menyerah berupaya melawan serta mengusir para penjajah Belanda dari bumi Indramayu. Untuk menyokong misinya itu kelengkapan senjata dan peralatan tempur jelas sangat dibutuhkan, tak pelak selain menyerang para pasukan gerilyawan pun merampas persenjataan milik tentara Belanda.

Serangan pasukan M.A. Sentot tidak hanya melumpuhkan mobilisasi tentara Belanda, tetapi juga merampas aset mereka demi kepentingan Republik Indonesia yang baru merdeka. Serangan yang kemudian dikenal sebagai "peristiwa Bankir", misalnya, telah membuat pasukan Republik Indonesia memiliki truk rampasan dan kendaraan militer lainnya.

Dari berbagai aksi heroik yang dikisahkan di atas, menjadikan suatu bukti konkret perlawanan melawan Belanda di Indramayu yang digencarkan oleh M.A. Sentot beserta pasukannya. Sebagai wujud reflleksi pula betapa sulitnya untuk menundukkan Kabupaten Indramayu, Belanda yang awalnya hendak menguasai secepat mungkin, akan tetapi diluar perkiraan mereka ternyata upaya mewujudkan kehendak tersebut tidaklah mudah. Komposisi pasukan M.A. Sentot yang solid dan mampu melakukan gangguan kepada pihak Belanda secara signifikan, disertai aksinya yang secara terorganisir dan memiliki mobilitas tinggi, realita itu benar-benar "mengamatirkan" para petinggi tentara Belanda yang berkedudukan di Indramayu.

Berbagai macam cara dilancarkan pihak Belanda untuk melenyapkan perjuangan wong Dermayu, sebagai misal melakukan aksi penyerangan secara frontal. Namun tetap saja, seolah rasa ketakutan yang ditimbulkan oleh Belanda masih kalah kuat dengan hasrat untuk merdeka sepenuhnya, sehingga tak berpengaruh signifikan terhadap intensitas dan eksistensi perjuangan itu sendiri.

Selain melancarkan gangguan serta penghadangan, pasukan di bawah komando M.A. Sentot juga mengalami serangan. Meskipun serangan dari tentara Belanda terencana dan relatif besar, namun pasukan M.A. Sentot yang telah malang melintang dalam berbagai pertempuran, tidak pernah kendur semangatnya. Berbagai prestasi dalam pertempuran mereka raih dengan sedemikian rupa sehingga tentara Belanda tidak bisa tidur nyenyak.

Kehebatan kelompok gerilyawan di Indramayu telah membuka mata masyarakat bahwa keberadaan pasukan 
Indonesia memang kuat. Belanda dipaksa untuk menyusun berbagai rencana baru untuk menghadapi pasukan tersebut.

Sejatinya perlawanan terhadap Belanda di Indramayu tidak hanya dilakukan tentara dan laskar saja, melainkan adanya andil dan sumbangsih rakyat yang mempunyai "semangat 45". Hal itulah yang seolah mampu menampar muka "wong londo" itu dan kontan memberikan pelajaran bahwa "wong dermayu" tak bisa diremehkan begitu saja.

Pada saat itu, muncul perlawanan dari para pejuang Indramayu. Tokoh-tokoh yang terkenal sebagai pejuang yang gagah berani selain M.A. Sentot, di antaranya adalah R. Achmad Wiroadisupatma, M.S. Sucita Warsono, Suyogo, Mayor sangun, dan Dr. Sudiro. Semangat pantang menyerah dari para pejuang inilah yang membuat Belanda kesulitan untuk menguasai kembali Kabupaten Indramayu.

\section{Nilai-Nilai Perjuangan M.A. Sentot}

Menelisik nilai-nilai perjuangan M.A. Sentot sejatinya tidak hanya dikaji pada subbab yang bertema "nilai-nilai perjuangan M.A. Sentot" ini saja. Dalam penelitian ini secara garis besar lebih mengedepankan nilai-nilai heroik serta perjuangan dari seorang bunga bangsa bernama M.A. Sentot di awal masa kemerdekaan.

Menjalani kehidupan sebagai pejuang di masa kemerdekaan benar-benar tidaklah mudah untuk dijalani. Begitu beratnya tanggung jawab yang diemban oleh mereka. Selain kewajiban melawan penjajah, melindungi rakyat serta mempertahankan kemerdekaan, para pejuangpun dihadapkan pada kondisi yang pelik, penuh tantangan, disertai pula dengan risikonya yang berakibat fatal. Pertaruhan dari perjuangan demi bangsa dan negara berisiko pada nyawa mereka sendiri. Bahkan terdapat kemungkinan terburuk lainnya yang lebih dari sekadar itu, tidak hanya diri sendiri yang menanggung akibatnya melainkan anggota keluarga pun dapat terkena imbasnya. Hal yang dimaksud pernah dialami oleh M.A. Sentot. Status ia di masa kemerdekaan sebagai satu di antara musuh dan buruan kelas "kakap" bagi Belanda yang berkedudukan di Indramayu, terlebih Belanda begitu membenci M.A. Sentot karena segala sepak terjang bersama pasukannya, telah menyebabkan orangtuanya mengalami peristiwa yang sangat mengenaskan.

Akibat hasutan Belanda, rumah orang tua M.A. Sentot (H. Abdul Kahar) di Plumbon dijarah massa yang terhasut. Orang tua M.A. Sentot tidak saja disiksa, namun isi rumahnya dirampas dan seluruh hartanya diambil (termasuk alat-alat rumah tangga, gamelan, satu gudang padi, dan dua lumbung padi). Rumah $\mathrm{H}$. Abdul Kahar kemudian dibakar. Hal ini tidak menjadikan nyali Sentot ciut melawan Belanda. Bahkan sebagai wujud aksi "counter attack", gangguan, serangan, dan penghadangan yang ditujukan terhadap tentara Belanda yang mendiami Kabupaten Indramayu semakin gencar dan semakin menggila dilakukan oleh M.A. Sentot bersama pasukan yang dipimpinnya.

Sejarah mencatat, terdapat pengalaman pilu yang menjadi bagian dari perjuangan di masa perang kemerdekaan, suatu kisah yang tidaklah ringan untuk dijalani oleh para pejuang. Namun para bunga bangsa itu senantiasa lakukan dengan rasa keikhlasan dan jiwa kebersamaan yang tinggi, yakni kala terjadinya kisah Long March. Secara singkat, kisah Long March bermula saat tentara Republik Indonesia, khususnya para prajurit di bawah Komando Daerah Gerilya VI, diharuskan hijrah ke Jawa Tengah sebagai bukti kepatuhan atas perjanjian Renville antara Indonesia dengan Belanda. Namun ketika para prajurit asal Indramayu kembali dari Jawa Tengah menuju Jawa Barat, mereka lakukan dengan cara berjalan kaki (Long March), berbeda di saat keberangkatannya yang diantar kereta api.

Kisah Long March merupakan bagian dari perang kemerdekaan yang 
dialami para pejuang dari Kabupaten Indramayu. Perang kemerdekaan ini termasuk lama, yaitu terjadi pada rentang waktu 1945 sampai 1950. Peristiwa Long March tentara Republik Indonesia yang terjadi dalam rentang waktu ini, dialami pula oleh M.A. Sentot dan anggotanya.

Peristiwa Long March itu dapat dijadikan indikator nyata betapa tingginya dedikasi yang dimiliki oleh tentara Republik Indonesia pada masa perang kemerdekaan, khususnya bagi M.A. Sentot yang memimpin pasukannya. Meskipun jarak tempuh dengan berjalan kaki tersebut terlampau jauh, dari Jawa Tengah ke Jawa Barat, namun mereka menjalaninya berlandaskan semangat yang tak pernah kendur. Tekad yang selalu membara dan kesadaran akan tanggung jawab yang tetap dipegang teguh.

Secara menyambung, sedikit flashback sebelum peristiwa Long March berlangsung, peristiwa yang dimaksud ialah ketika terjadinya momentum "hijrah". Sebagai pasukan yang patuh pada perintah pimpinan, para prajurit atau gerilyawan meninggalkan kantung-kantung gerilya di Indramayu secara serempak, secara sukarela menuju lokasi yang telah ditetapkan oleh pimpinan tentara Republik Indonesia. Begitu luar biasanya kepatuhan dan pengabdian mereka pada satu pucuk perintah sekalipun tidak semudah membalikkan telapak tangan. Bayangkan, mereka diharuskan meninggalkan kantungkantung gerilya di basis perjuangan masing-masing, baik kantung-kantung gerilya yang berada di kampung-kampung, hutan ataupun di tempat yang lain, dikala tentara-tentara Belanda masih menebar ancaman-ancaman kepada rakyat. Tidaklah mengherankan perasaan dilematis pun sempat menghinggapi para prajurit dari Indramayu itu. Tetapi sekali lagi, sebagai bukti kepatuhan serta pengabdian, bagi M.A. Sentot dan pasukannya memahami bahwa kesemuanya itu hanyalah suatu bagian dari perjuangan yang harus mereka hadapi dengan tabah, dijalani dengan gigih dan tak boleh menggoyahkan semangat perjuangan.

Adapun kisah serupa yang mempunyai korelasi dengan peristiwa hijrah dan Long March yang dijalani oleh M.A. Sentot ialah sewaktu seluruh pasukan dari Jawa Barat masih berada di Jawa Tengah. Segalanya berawal saat para pimpinan militer Indonesia menyadari akan situasi yang semakin gawat serta hijrahnya para pasukan militer dari daerah kantung-kantung gerilya di Jawa Barat ke Jawa Tengah merupakan strategi yang salah. Letak kesalahannya tersebut karena kantung-kantung gerilya di daerah menjadi kosong dari kekuatan militer Indonesia. Akibatnya daerah-daerah itu rawan dari berbagai gangguan, baik yang datang dari dalam ataupun luar daerah.

$$
\text { Sebagai buktinya, pasukan }
$$

Hizbullah, yang kemudian berubah menjadi Darul Islam (DI). Mereka memanfaatkan kekosongan kantungkantung gerilya dengan menduduki daerahdaerah yang tidak dijaga tentara Republik Indonesia. Tidak hanya itu, pasukan Hizbullah konon melakukan keganasan kepada rakyat, telah menimbulkan berbagai penderitaan. Berkaca pada perkembangan situasi keamanan yang demikian, lantas seluruh pasukan yang berasal dari Jawa Barat diinstruksikan untuk segera kembali pulang dan melenyapkan gangguan para "pengacau pribumi" tersebut.

Berkat kesigapan M.A. Sentot dan para prajurit lainnya yang telah kembali dari Jawa Tengah, keganasan pasukan Hizbullah yang telah berpaling dari Republik Indonesia bisa segera dibasmi. Secara perlahan tapi pasti, kepercayaan rakyat terhadap eksistensi militer Republik Indonesia tumbuh kembali. Rakyat menyadari bahwa Tentara Republik Indonesia masih ada dan bisa diandalkan untuk menjadikan hidup mereka lebih tenteram (Kasmadi, (89 tahun) prajurit seperjuangan Sentot. Patrol, 5 November 2017). 


\section{PENUTUP}

Dari pembahasan di atas penulis menyimpulkan bahwa Sentot lahir pada tanggal 17 Agustus 1925 dengan nama Muhammad Asmat Sentot. Ayahnya bernama H. Abdul Kahar dan ibu bernama $\mathrm{Hj}$. Fatimah. Namanya mulai dikenal ketika masuk Tentara Keamanan Rakyat (TKR), karirnya mulai menanjak sejak didaulat menjadi komandan kesatuan gerilya wilayah Indramayu. Beberapa pertempuran untuk menggagalkan konvoy pasukan Belanda di antaranya adalah pertempuran Bangkir, Pertempuran Sindang, pertempuran Waledan, Pertempuran Bunder dan darah-daerah lain di Indramayu yang semuanya dimenangkan oleh Sentot. Pasukannya disebut Pasukan Setan.

Selama Perang Revolusi Fisik 1945 M.A.Sentot tampil sebagai pejuang yang berada di garis depan pertempuran. Seperti yang telah dikaji bahwa di Indramayu ia memimpin berbagai penyerangan ke markas-markas tentara Belanda, memutus mata rantai pasukan Belanda, menggempur pos-pos markas Belanda di setiap distrik militer di Indramayu dan menggagalkan logistik perang Belanda. Tujuannya untuk mempertahankan kemerdekaan RI dan mengusir penjajah. Perjuangan gerilya Sentot di Indramayu diakhiri ketika Indonesia diakui kedaulatannya secara de jure dan de facto 27 Desember 1949 oleh Belanda dan dunia Internasional.

\section{DAFTAR SUMBER}

\section{Data Dokumen}

Dokumen Piagam penghargaan dan Lencana Kemiliteran.

Foto-foto Koleksi keluarga.

\section{Jurnal}

Jurnal sejarah vol. 6 No. 1 Agustus 2004 , Pemikiran, Rekontruksi, Persepsi, Tilly "Collective Action" Revolusi Kisah Tawanan Boven Digul. Diterbitkan oleh
Yayasan Masyarakat Sejarawan Indonesia.

\section{Buku}

Badan Koordinasi Pembangunan Daerah Jawa Barat, 1965.

Sejarah Perkembangan Pembangunan Daerah Jawa Barat Tahun 1945-1965. Bandung: Koordinasi Pembangunan Tingkat I Jawa Barat.

Dinas Sejarah Militer TNI-AD. 1977. Album Perjuangan TNI AD Periode 1945-1950. Bandung: Dinas Sejarah TNI AD.

Ekajati, Edi S. 1992.

Kebudayaan Sunda Jilid I: Kebudayaan Desa. Bandung: Jurusan Sejarah Fakultas Sastra Universitas Pajajaran.

Idris, Wawan, 2008.

M.A. Sentot dalam Arus Sejarah Nasional Indonesia. Bandung: Satuangit.

Kartodirdjo, Sartono. 1992.

Pengantar Sejarah Indonesia Baru: Sejarah Pergerakan Nasional. Jakarta: Gramedia Pustaka Utama.

Louis Gottschalk, 1995.

Mengerti Sejarah, terjemah Nugroho Notosusano, penerbit: UI Press, Jakarta.

Nasution, A.H. 1984.

Pokok-Pokok Gerilja dan Pertahanan Republik Indonesia Dimasa Jang Lalu dan Jang Akan Datang. Jakarta: Angkasa.

Reid, J.S . 1964.

Revolusi Indonesia. New York:

Cornell Modem Indonesia

Project.

\section{Wawancara Narasumber}

Thohir Veteran Indramayu (83) pejuang jaman Jepang hingga Agresi Militer Belanda II.

Alamsyah, (66 tahun), anak kandung M.A Sentot

Kasmadi, (89 tahun) prajurit seperjuangan Sentot. Patrol, 5 November 2017. 